\title{
Sínodo da Amazônia: o olhar da lgreja sobre o drama vivido pelos povos indígenas e pela
} natureza

\author{
Amazon Synod: the Church's view on the \\ drama lived by the indigenous peoples and \\ the nature
}

Antônio Lopes Ribeiro ${ }^{1}$

\begin{abstract}
Resumo
Devido à consciência global sobre a sustentabilidade da vida no planeta, o olhar de muitos organismos internacionais está voltado para a floresta amazônica, a fim de lutar pela preservação de suas imensuráveis fontes hídricas e rica biodiversidade em sua fauna e flora, que juntamente com os povos indígenas que a habitam, vivem o drama de uma iminente extinção. Por meio de uma pesquisa bibliográfica, propomos mostrar neste artigo os avanços da atuação da Igreja católica, com a realização do Sínodo da Amazônia, que com suas denúncias e propostas pastorais, se junta ao clamor mundial pela preservação da floresta amazônica e da vida dos povos indígenas.
\end{abstract}

Palavras-chave

Povos indígenas. Natureza. Ecologia integral. Sustentabilidade.

\section{Abstract}

Due to the global awareness about the sustainability of life on the planet, the eyes of many international organizations are turned to the Amazon rainforest, with the intent to fight for the preservation of its immeasurable water sources and rich biodiversity in its fauna and flora, which together with the indigenous peoples that inhabit it, live the drama of imminent extinction. In this article, we show, through a bibliographic search, the advances of the Catholic Church's actions, which with the holding of the Amazon Synod and its denunciations and pastoral proposals, joins the world's cry for the preservation of the Amazon raiforest and the of indigenous peoples' lives.

Keywords

Indigenous peoples. Nature. Integral ecology. Sustainability.

\section{INTRODUÇÃO}

No momento da criação, o mundo em que vivemos foi destinado a ser um "jardim das delícias terrenas", como magnificamente o expressou Hieronymus Bosch, na arte pictórica, ou o que Aloysius Pieris (2011, p. 192) chama de um "parque dos prazeres". Pode-se dizer que esse lugar paradisíaco ainda existe concretamente: a floresta amazônica, que devido ao desmatamento, encontra-se ameaçada de extinção. Mas, não só a floresta, com sua riquíssima biodiversidade, tende a desaparecer, a continuar a agressão que vem sofrendo, com derrubada de

\footnotetext{
${ }^{1}$ Doutor e mestre em Ciências da Religião pela Pontifícia Universidade Católica de Goiás (PUC Goiás). Especialista em Diálogo Ecumênico e Inter-religioso pelo Instituto Teológico de Santa Catarina (ITESC/FAJE). Bacharel em Teologia pela Faculdade de Teologia da Arquidiocese de Brasília (FATEO). Pós-doutorado em Teologia pela Pontifícia Universidade Católica do Paraná (PUCPR). Professor do Programa de Pós-Graduação em Teologia da FATEO. Contato: lopesribeiroa@ gmail.com.
} 


\section{Revista Brasileira de Diálogo Ecumênico e Inter-religioso}

árvores e queimadas. Os povos originários, que nela habitam há milhares de anos, também perecerão. Esse duplo drama remonta aos tempos da colonização, em que essa vida paradisíaca dos povos indígenas começou a ser desfeita, tornando-se um pesadelo, resultando em verdadeira tragédia, que se abateu sobre suas aldeias, abortando vidas e histórias (ZWETSCH, 1996, p. 53).

Numa mescla de fé e conquista, o sistema de colonização, que se implantou por aqui, não respeitou os povos originários, resultando num processo de deculturação, em que sua cultura, seus valores, sua religião, foram simplesmente ignorados pelos europeus. Os povos indígenas, em sua grande maioria, foram esmagados e tiveram "suas culturas dominadas e condenadas por estruturas e ideologias homogeneizantes", e muitos perderam suas vidas, diz Heck (1999, p. 15). Inúmeras foram as atrocidades cometidas pelos conquistadores em nome do catolicismo medieval. Mas não estavam sós. Faziam-se acompanhar por missionários, com a missão de cristianizar este continente. Em tudo o que fizeram, havia a legitimação da Igreja, pelo poder a eles concedido pelo sistema de padroado, motivados pela ideologia da cristandade.

Na discutível comemoração dos 500 anos do descobrimento da América, a pergunta que se fazia era: a evangelização foi libertadora ou motivo de opressão? Profetas, como Bartolomé de Las Casas, reagiram contra a mentalidade do seu tempo. Porém, a grande maioria não teve sabedoria e impôs aos povos indígenas a cultura europeia, juntamente com o Evangelho. Em tempos de nova evangelização, torna-se necessário rever tudo o que aconteceu, em vista a reparar os danos causados. Como afirma Giaccaria (1991, p. 108), estrago esse "que não foi a Bíblia, nem o Evangelho que introduziram, mas uma interpretação errada de homens demasiado ligados ao poder, à conquista, à colonização".

Hoje, em sua opção pelos pobres, a Igreja católica coloca-se ao lado dos povos indígenas e da natureza, também feitos pobres, com os quais, devido à fraternidade que lhes fora negada no passado, quando não se respeitou sua alteridade, é devedora. Não sem razão, ela realiza o Sínodo da Amazônia, a fim de colocar-se na dianteira daqueles olhares que se voltam para aquela região, com o objetivo de lutar pela preservação da natureza, bem como da vida de seus habitantes, os quais estão em perigo de extinção.

\section{O DRAMA DA FLORESTA AMAZÔNICA SOB AMEAÇA DE EXTINÇÃO}

Hoje há um clamor no mundo inteiro, no sentido da preservação da natureza, sob pena de a humanidade não sobreviver. Não sem razão, o olhar de muitos organismos internacionais está voltado para a floresta amazônica, com suas imensuráveis fontes hídricas, apresentando uma riquíssima biodiversidade em sua fauna e flora. Apesar disso, torna-se uma das regiões mais empobrecidas, devido à lógica de dominação e exploração, bem como da negligência óbvia dos governos dos países que lhe são fronteiriços (ROJAS, 2012). Contrariando a ordem dada por Deus ao homem, de cuidar do Jardim do Éden, devido a uma lógica desenvolvimentista, irracional e estúpida, que visa o acúmulo de capitais, e de uma produção desenfreada de bens, a floresta amazônica vem sendo sistematicamente destruída, trazendo Caminhos de Diálogo, Curitiba, ano 8, n. 12, p.77-90, jan./jun. 2020

78 ISSN 2595-8208 
graves consequências para os povos que nela habitam. De uma atitude amigável, na sua relação com a natureza, o ser humano passou a uma atitude voraz e predatória, cuja tendência é "espremer a realidade até o esgotamento de todos os recursos naturais disponíveis" (DSA 71). Conforme Chambe (2010, p. 44), aqueles que devastam a natureza, seguindo regras do mercado capitalista, que reduz a vida humana e a Terra ao cálculo meio-fim, esquecem-se de que "a vida da Terra não é um meio para acumular riquezas, mas condição de possibilidade de viver".

A sustentabilidade da vida no planeta Terra é de interesse mundial e dependente de uma consciência solidária, igualmente global. A humanidade atinge uma era planetária, significando "que além das divergências de raça, cultura e religião, os homens têm consciência de habitar uma 'casa comum' e de pertencer a uma única família” (GEFFRÉ, 1997, p. 112). Com efeito, há uma nova consciência emergente, ao mesmo tempo planetária e ecológica, de que somos uma só humanidade. Mais do que nunca, é preciso assumir uma visão planetária mundial e holística, e chegar a um consenso sobre uma ética mundial (GARAY, 2006, p. 268). Assim, tudo aquilo que põe a vida em perigo (guerra nuclear, devastação ecológica, violência étnica), exige "soluções unificadas, combinadas, cooperativas" (KNITTER, 2008, p. 57). Porém, como defende Irarrázaval (2003), não se deve esquecer que o desenvolvimento de uma solidariedade mundial não pode separar-se do dinamismo do cosmos e da qualidade espiritual dos povos, valendo a interação dos setores da humanidade, que se ocupam com a luta pela preservação da natureza, com as comunidades indígenas, com as quais temos muito a aprender.

Conforme Tamayo (2011, p. 36), geralmente as religiões têm em comum "princípios éticos fundamentais em favor da paz, da justiça, da igualdade dos seres humanos e da defesa da natureza". Segundo Garay (2006, p. 272), é comum nas religiões "o sonho de um mundo novo, de outra humanidade, na qual já não existe o mal, a ignomínia, o opróbrio, o egoísmo, a morte". Nisto, temos muito a aprender com os povos indígenas, cujo ethos integra a pessoa ao ambiente em que vive, tão estreitamente relacionados, que para eles tudo é vida. Por milhares de anos, cuidaram muito bem de sua terra, águas, florestas, conseguindo preservá-las até hoje, a fim de que "a humanidade possa beneficiar do usufruto dos dons gratuitos da criação de Deus" (DSA 14). Outrora ignorados, os povos indígenas passam a ser protagonistas frente à necessidade mundial de se preservar a natureza contra a estúpida depredação por parte do ser humano. Segundo Arconada (2010), o movimento indígena "é um ator que não só resiste e luta para que se deem verdadeiros processos de descolonização", mas são verdadeiros protagonistas na luta por seu direito de habitar a terra que lhes viu nascer, em defender a Mãe Terra contra a exploração dos recursos naturais, como também em propor formas alternativas de vida, uma verdadeira descolonização do poder e do saber, e uma desmercantilização da vida.

Os padres sinodais mostraram-se atentos à grande contribuição que pode ser dada pelos povos indígenas na luta mundial pela sustentabilidade da vida no planeta. Na opinião deles, a visão integradora da realidade, que faz parte dos valores dos povos indígenas, é "capaz de compreender as múltiplas conexões existentes entre tudo o que foi criado", contrastando com a 


\section{Revista Brasileira de Diálogo Ecumênico e Inter-religioso}

corrente dominante do pensamento ocidental, cuja tendência é "fragmentar-se para compreender a realidade, mas não consegue articular novamente o conjunto de relações entre os vários campos do conhecimento". Conforme o Documento final do Sínodo da Amazônia (DSA 44), aquilo que os povos indígenas tradicionalmente vêm fazendo, no manejo com a natureza, tornase o que se conhece por manejo sustentável. Além disso, tem outros valores importantes, para um mundo sustentável, que é "a reciprocidade, a solidariedade, o sentido de comunidade, a igualdade, a família, sua organização social e o sentido de serviço" (DSA 44).

Portanto, para vencer a agressão contra a floresta amazônica, a Igreja reconhece o quanto tem a aprender com os povos indígenas. O novo paradigma do desenvolvimento sustentável, defendido por muitos países e organismos internacionais, "deve ser socialmente inclusivo, combinando conhecimentos científicos e tradicionais, para empoderar as comunidades tradicionais e indígenas, em sua maioria mulheres, fazendo com que estas tecnologias sirvam ao bem-estar e à proteção das florestas" (DSA 71). Com efeito, no trato com a questão ecológica, a doutrina social da Igreja se enriquecerá com a contribuição dos povos indígenas, no sentido de uma nossa conversão a uma ecologia integral. Esses povos têm uma forma especial de se relacionar e proteger seus territórios, sendo luz para a criação de “ministérios para o cuidado da 'casa comum' na Amazônia, que tenham como função cuidar do território e das águas junto com as comunidades indígenas" (DSA 79).

Se a natureza padece e necessita de cuidados, os povos indígenas que a ela se encontram interligados também necessitam de cuidado, pois devido à atuação irresponsável e estúpida do ser humano, estão sendo destruídos juntamente com a natureza, ou forçados a abandonar suas terras, saindo de seu habitat natural.

\section{O DRAMA DOS POVOS INDÍGENAS DA AMAZÔNIA}

Junto ao drama da floresta amazônica, encontram-se os povos indígenas, que sofrem, consequentemente, com sua destruição. Eles têm sido historicamente ignorados de tal forma, “como se não existissem e como se as terras onde habitam não lhes pertencessem", diz o papa Francisco, em Querida Amazônia (QA 12). Para Darcy Ribeiro (1992), até hoje os índios são tratados como estrangeiros e exóticos na própria terra onde habitam. Qualificando-os de préhistóricos, não poucas vozes contemplam o índio como radicado no passado (atitude que o agride). Não percebem que o índio, por todo seu conhecimento, "pertence ao presente e ao nosso futuro plenamente humano e cristão" (IRARRÁZAVAL, 2003, p. 93). Na opinião do papa Francisco, a identidade desses povos tem sido desconsiderada até mesmo nos programas educacionais de crianças e jovens, em que os indígenas são vistos como intrusos e usurpadores, "considerando-os mais como um obstáculo de que nos temos de livrar, do que como seres humanos, com a mesma dignidade que qualquer outro e com direitos adquiridos" (QA 12).

Conforme o Documento final do sínodo (DSA 6-7), hoje a Amazônia é uma beleza ferida e deformada, tornando-se um lugar de dor e violência, com graves consequências, Caminhos de Diálogo, Curitiba, ano 8, n. 12, p.77-90, jan.jun. 2020

80 ISSN 2595-8208 
principalmente para a população indígena, que fica exposta não somente à exploração de seus territórios, mas ao tráfico de pessoas, à venda de órgãos, ao turismo sexual, à perda da cultura e identidade originais (linguagem, práticas e costumes espirituais), à criminalização e assassinato de seus líderes e defensores de seus territórios (DSA 10). Além de todo tipo de discriminação, os ataques aos povos indígenas têm sido constantes, desde simples ameaças a homicídios. De acordo com Pádua (1999, p. 144), "precisamos ter em conta que vivemos numa parte do mundo na qual a vida dos pobres foi sempre sacrificada em favor de agentes externos. Isso vem ocorrendo nestes últimos cinco séculos", com os povos indígenas.

De acordo com os padres sinodais (DSA 9), a vida em abundância na Amazônia é um dos motivos pelos quais os povos indígenas procuraram, desde os tempos arcaicos, se estabelecer na região, concretizando seu ideal de "bem viver", que consiste em "viver em harmonia consigo mesmo, com a natureza, com os seres humanos e com o ser supremo", pois em sua visão de mundo "existe uma intercomunicação entre todo o cosmos, onde não há exclusões", onde torna-se possível "forjar um projeto de vida para tudo". Na verdade, os povos indígenas sustentam uma visão de mundo, em que a vida "é caracterizada pela conectividade e harmonia das relações entre água, território e natureza, vida e cultura comunitária, Deus e as várias forças espirituais". O "bom viver" por eles concebido tem por centralidade o "caráter relacional transcendente dos seres humanos e da criação, e supõe um 'bom fazer'”, que é a forma integral por meio da qual "se expressa em sua própria maneira de organizar essa parte da família e da comunidade, e que abrange um uso responsável de todos os bens da criação". É meta do projeto do bem viver, alcançar melhores condições de vida, sobretudo saúde e educação, por meio de um desenvolvimento sustentável, que tem por protagonistas eles próprios, a fim de manter a harmonia entre "seus modos de vida tradicionais, dialogando entre a sabedoria e a tecnologia de seus ancestrais e os novos adquiridos" (DSA 9).

Um dia, as terras que hoje ocupamos foram dos povos indígenas. Mas, aos poucos, elas lhes foram sendo tiradas pelos invasores. A ganância pela terra da Amazônia tem sido a raiz dos diversos conflitos que geraram etnocídio, assassinato e a criminalização dos movimentos sociais e de suas lideranças. É obrigação do Estado brasileiro demarcar e proteger a terra dos povos indígenas. Contudo, a realidade é outra, pois grande parte de seus territórios está desprotegida e as áreas que já estão demarcadas são constantemente invadidas "por frentes extrativistas como mineração e extração florestal, por grandes projetos de infraestrutura, por cultivos lícitos e por grandes propriedades que promovem a monocultura e a pecuária extensiva" (DSA 45).

O sínodo destacou o fenômeno da migração de povos indígenas para áreas mais pobres e piores, das periferias das cidades, quando "expulsos de seus territórios ou atraídos pelo falso brilho da cultura urbana" (DSA 12-13). Na opinião do papa Francisco (QA 21), com a emigração para a cidade, torna-se mais intenso ainda o efeito desintegrador do desenraizamento em que vivem os povos indígenas. Alí geralmente viverão "de forma não digna, no meio dos costumes urbanos mais individualistas e dum ambiente hostil". Na cidade, veem suas famílias 


\section{Revista Brasileira de Diálogo Ecumênico e Inter-religioso}

desintegradas, afetando a transmissão dos valores, pois é por meio da família que uma tradição mantém viva sua cultura. Além disso, sofrem com a invasão colonizadora maciça dos meios de comunicação, tornando-se necessária a promoção de comunicações alternativas, "a partir das suas próprias línguas e culturas", fazendo com que "se façam protagonistas presentes nos meios de comunicação já existentes". Em vistas a sanar um dano tão grave e reconstruir essas vidas desenraizadas, o papa propõe que se valorize e acompanhe "todos os esforços que fazem muitos desses grupos para preservar os seus valores e estilo de vida e integrar-se nos contextos novos sem os perder", pois são de grande valia para o bem comum. (QA 39).

O sínodo relembra que os países que fazem parte da região amazônica defendem os direitos humanos dos povos indígenas (DSA 69). O sumak kawsay, por exemplo, que na língua quíchua significa "bem viver", consta nas constituições da Bolívia e Equador, enquanto meta social a ser perseguida pelo Estado e por toda a sociedade (BOFF, 2012, p. 66). Contudo, no Brasil, os legisladores têm favorecido a invasão de seus territórios, com a ampliação de fronteiras extrativistas de seus recursos naturais, bem como fomentando o desenvolvimento de megaprojetos de infraestrutura, exercendo, por conseguinte, pressão sobre os territórios ancestrais indígenas. Outro fator grave a se considerar é o crescimento da "situação de impunidade na região em relação a violações de direitos humanos e de obstáculos na obtenção de justiça" (DSA 69), o que tende a piorar no governo atual, que tem manifestado publicamente pouco interesse pela questão indígena, engavetando projetos de demarcação de suas terras.

A Igreja reunida no Sínodo da Amazônia coloca-se ao lado dos povos indígenas, com o propósito de exercer sua voz profética, denunciando as injustiças cometidas contra eles e contra a natureza, bem como desenvolvendo ações pastorais voltadas à preservação da floresta amazônica, e da vida de todos os que nela habitam.

\section{PROPOSTA PASTORAL DA IGREJA}

A mudança de perspectiva missionária da Igreja, no sentido de reverter a situação dramática em que vivem os povos indígenas, bem como a natureza, que mais se destacou até agora, tem sido a do Conselho Indigenista Missionário (Cimi). Passa-se radicalmente "de uma perspectiva integracionista para a de autodeterminação dos povos indígenas, e da luta intransigente pelos direitos desses povos, especialmente à sua terra". Assim, observa-se uma substancial mudança no ponto de vista da teologia da missão, no sentido da superação de uma perspectiva corporativa, pela via do diálogo e valorização das religiões indígenas, "partindo do princípio de que a religião de cada povo é a melhor resposta dentro de sua cultura e sociedade" (HECK, 1999, p. 17). Portanto, o Sínodo da Amazônia não acontece num vácuo. A Igreja já se faz atuante na região amazônica, lutando pela proteção da natureza e da vida dos próprios indígenas. O sínodo reconhece com admiração o esforço daqueles que colocam sua vida em grande risco, a fim de defender a existência da Amazônia, muitos dos quais deram suas vidas na

Caminhos de Diálogo, Curitiba, ano 8, n. 12, p.77-90, jan./jun. 2020

82 ISSN 2595-8208 
luta por uma ecologia integral naquele território (DSA 16), como Chico Mendes, Dorothy Stang, Ezequiel Ramin, dentre outros.

Enquanto aliada dos povos amazônicos e consciente de que a defesa da terra tem por finalidade a defesa da vida humana, é missão da Igreja, compromissada com a promoção e salvação integral da pessoa humana, exercer sua voz profética, denunciando "os ataques contra a vida das comunidades indígenas, os projetos que afetam o meio ambiente, a falta de demarcação de seus territórios, bem como o modelo econômico de desenvolvimento predatório e ecocida" (DSA 46). Em razão disso, valoriza a cultura desses povos, "falando de suas necessidades vitais, acompanhando os movimentos em suas lutas por seus direitos", no exercício de sua ação pastoral, que outra finalidade não tem do que colocar-se a "serviço da vida plena dos povos indígenas" (DSA 48). Como metas de atuação, o sínodo estabeleceu algumas prioridades, em sua agenda pastoral, visando proteger a vida na floresta amazônica.

\subsection{Por uma ecologia integral}

Considerando o planeta como um dom de Deus, o sínodo reconhece a urgência de agir, perante a crise socioambiental sem precedentes, que envolve toda a Amazônia, colocando em risco todo seu bioma, ameaçando-o de extinção, com consequências incalculáveis para o planeta. Ao reconhecer as feridas causadas pelo ser humano, Igreja propõe uma ecologia integral, dispondo-se a aprender com os povos originários, pela via do diálogo de saberes, a fim de "dar novas respostas, buscando modelos de desenvolvimento justo e solidário" (DSA 65). Ao dar a Terra ao ser humano, como um dom, Deus deu junto a tarefa de cuidar bem dela. O homem é seu porta-voz, mas não seu dono. A Igreja entende que perante "a situação premente do planeta e da Amazônia, a ecologia integral não é mais um caminho" que possa eleger para o futuro, mas é o único caminho que lhe resta, não havendo "outra estrada viável para salvar a região", lembrando que junto à depredação do território, vem o "derramamento de sangue inocente e da criminalização dos defensores da Amazônia" (DSA 66-67).

Conforme o sínodo, o futuro da Amazônia é responsabilidade de todos, cabendo a nós sermos "guardiões da obra de Deus". Isto implica, de imediato, o abandono do modelo de desenvolvimento atual, que destrói a floresta e não traz bem-estar, colocando em perigo tão imenso tesouro natural, juntamente com seus habitantes. Para proteger a floresta amazônica, o sínodo se alia aos povos originários daquele território, bem como a seu horizonte do "bem viver". Chama todos a "uma conversão ecológica individual e comunitária que salvaguarde uma ecologia integral e um modelo de desenvolvimento em que os critérios comerciais não estejam acima do meio ambiente e dos direitos humanos", propondo a geração de alternativas de desenvolvimento ecológico integral, desde as "cosmovisões construídas com as comunidades, resgatando a sabedoria ancestral". Além disso, sinaliza apoio a "projetos que proponham uma economia solidária e sustentável, circular e ecológica, tanto em nível local, como internacional, no âmbito da pesquisa e no campo de ação, nos setores formal e informal" (DSA 73).

Caminhos de Diálogo, Curitiba, ano 8, n. 12, p. 77-90, jan./jun. 2020 
Revista Brasileira de Diálogo Ecumênico e Inter-religioso

Portanto, o sínodo reconhece a necessidade de uma profunda conversão em nível pessoal, social e estrutural, a fim de defender a vida da Amazônia, na qual a Igreja se inclui. Conforme o sínodo, há um novo colonialismo, cuja força se faz presente em nossas decisões cotidianas, bem como no desenvolvimento predominante, sobre o qual devemos nos conscientizar. Ele se expressa "no crescente modelo agrícola de monocultura, em nossos modos de transporte e no imaginário do bem-estar a partir do consumo que vivemos na sociedade, que tem implicações diretas e indiretas na Amazônia" (DSA 81). É preciso a adoção de "hábitos responsáveis que respeitem e valorizem os povos da Amazônia, suas tradições e sabedoria, protegendo a terra e mudando nossa cultura de consumo excessivo, a produção de resíduos sólidos, estimulando o reaproveitamento e a reciclagem”. Outras vias alternativas apontadas incluem o plantio de árvores, bem como alternativas sustentáveis na agricultura, energia e mobilidade, de forma a respeitar os direitos da natureza e dos povos. Fomenta ainda uma educação voltada à ecologia integral, por meio da implementação de "novos modelos econômicos e iniciativas que promovam uma qualidade de vida sustentável” (DSA 84).

\subsection{Por uma pastoral indígena}

Esta deve ocupar seu lugar específico na Igreja, a fim de favorecer uma proposta de evangelização das comunidades indígenas, as quais foram conduzidas a uma situação de alta vulnerabilidade, devido a colonizações motivadas pelo extrativismo, no decorrer da história, juntamente com as correntes migratórias. Há, com efeito, a necessidade de se criar ou manter uma opção preferencial para os povos indígenas, de forma que as organizações pastorais indígenas diocesanas possam estabelecer e concretizar uma ação missionária permanente e renovada, capaz de ouvir, dialogar e se encarnar. Consequentemente, "a opção preferencial pelos povos indígenas, com suas culturas, identidades e histórias, exige que aspiremos a uma Igreja indígena com nossos próprios padres e ministros sempre unidos e em total comunhão com a Igreja católica" (DSA 27). O deslocamento forçado de famílias indígenas, expulsas de seus territórios, por pressão ou asfixia, devido à falta de oportunidades, exige da Igreja uma pastoral conjunta para atuar na periferia dos centros urbanos, tornando-se necessária a criação de equipes missionárias, a fim de acompanha-los, seja na coordenação de condições de acolhida, na disponibilização de liturgias inculturadas e nas línguas dos migrantes, bem como na promoção de espaços de intercâmbio cultural, "favorecendo a integração na comunidade e na cidade e motivando-os neste trabalho a serem protagonistas" (DSA 29).

As comunidades indígenas que são forçadas a deixar seu habitat natural, migrando para as periferias das cidades, passam por um processo de embranqueamento, ao serem invadidas por "estilos de vida, formas de convivência, linguagens e valores moldados pelas metrópoles" (DSA 34). Este é outro ponto observado no sínodo, que requer uma maior atenção da Igreja, pois os povos indígenas "são os mais expostos aos enormes problemas da delinquência juvenil, falta de trabalho, lutas étnicas e injustiças sociais". Torna-se um dos maiores desafios para a Igreja, na Caminhos de Diálogo, Curitiba, ano 8, n. 12, p.77-90, jan./jun. 2020 
atualidade, o fato de que "cada vez mais cidades são destinos de todas as etnias e povos da Amazônia", sendo, portanto, necessária a articulação de "uma pastoral indígena da cidade que atenda a esta realidade específica" (DSA 37).

Uma das preocupações dos padres sinodais, com relação à atuação pastoral da Igreja a favor dos índios é a questão dos jovens indígenas, que juntamente com outros jovens da região, "diariamente sonham e buscam melhores condições de vida, com o profundo desejo de ter uma vida plena". São estudantes, trabalhadores e com presença e participação marcantes em diversos espaços sociais e eclesiais (DSA 30), com enorme potencial, participando "ativamente de suas comunidades e organizações, contribuindo como líderes e animadores, em defesa dos direitos, especialmente no território, saúde e educação". Esses mesmos jovens são submetidos aos vícios do álcool e das drogas, cujas consequências os impedem de "viver livremente para construir seus sonhos e participar ativamente da comunidade" (DSA 32). Diante dessa realidade, a Igreja coloca como prioridade pastoral promover novas formas de evangelização por meio das redes sociais; esforços no sentido de ajudar esses jovens indígenas "a alcançar uma sadia interculturalidade [...], a enfrentar a crise de antivalores que destrói sua autoestima e os faz perder sua identidade" (DSA 33). Consciente da necessidade de se preservar a própria cultura, o papa Francisco convida os jovens da Amazônia, sobretudo os indígenas, a "assumir as raízes, pois das raízes provém a força que [os] fará crescer, florescer e frutificar" (QA 33).

\subsection{Por uma educação dos povos indígenas}

Simultaneamente à busca por uma pecuária e agricultura sustentáveis, bem como energias não poluentes e fontes dignas de trabalho, que não impliquem a destruição do meio ambiente e às culturas indígenas, o papa Francisco defende que é preciso garantir uma educação que desenvolva as capacidades e empoderamento dos povos indígenas. Reconhece que a realização desses objetivos de nada "servirá para devolver aos mortos a vida que lhes foi negada, nem para compensar os sobreviventes daqueles massacres", mas hoje serve ao menos para sermos todos realmente humanos (QA 17). Com relação às ações educativas, que apresentam como desafio a necessidade de inculturação, o sínodo aponta para a importância de previamente se conhecer as línguas, crenças e aspirações, necessidades e esperanças, bem como "a construção coletiva de processos educativos que tenham, tanto na forma quanto no conteúdo, a identidade cultural das comunidades amazônicas, insistindo na formação de uma ecologia integral como eixo transversal" (DSA 57).

Os padres sinodais avançaram na proposta da criação de uma universidade católica amazônica, com atividades de pesquisa, educação e extensão, constando de seus programas, "estudos ambientais (conhecimento teórico baseado na sabedoria dos povos que vivem na região amazônica) e estudos étnicos (descrição das diferentes línguas etc.)”. A proposta de criação dessa universidade está voltada ao projeto de inculturação da fé cristã na América Latina, prevendo a formação de professores, bem como o ensino e produção de materiais didáticos 


\section{Revista Brasileira de Diálogo Ecumênico e Inter-religioso}

inculturados, de forma a "respeitar os costumes e as tradições dos povos indígenas, e realizando atividades de extensão em diferentes países e regiões" (DSA 114).

\subsection{Diálogo com os povos indígenas}

Como parte de uma Igreja missionária em saída, está o diálogo a ser estabelecido com os povos indígenas, em um clima de espiritualidade de escuta e anúncio. Conscientes de que as culturas indígenas não são terreno vazio, desprovido de autênticos valores, os padres sinodais mencionam a teologia índia como riqueza do cosmos indígena, de sua cultura e espiritualidade. Afirmam que "o mundo indígena com seus mitos, narrativas, ritos, cantos, danças e expressões espirituais enriquece o encontro intercultural". Ao contrário do passado, a evangelização da Igreja hoje não se dá como "um processo de destruição, mas de consolidação e fortalecimento desses valores; uma contribuição para o crescimento das 'sementes do Verbo"' (DSA 54).

Tendo os povos indígenas como interlocutores do diálogo em prol da defesa da vida, da integridade da criação, da paz, e do bem comum (DSA 23), a Igreja procurará estabelecer o diálogo inter-religioso, conscientes de que suas "tradições merecem ser conhecidas, entendidas em suas próprias expressões e em seu relacionamento com a floresta e a Mãe Terra”. Fomentase, então, uma oportunidade de os cristãos, movidos pela fé na Palavra de Deus, dialogar com os povos indígenas, compartilhando "suas vidas, preocupações, lutas e experiências de Deus, para aprofundar a fé um do outro e agir junto em defesa da casa comum". Para que isto se concretize, o sínodo aponta para a necessidade de que "as igrejas da Amazônia desenvolvam iniciativas de encontro, estudo e diálogo com os seguidores dessas religiões", de forma a tornar o diálogo sincero e respeitoso, em uma ponte para a construção do "bem viver" (DSA 25).

Assim, de ignorados que foram no passado, considerados uma tábula rasa, os povos indígenas da Amazônia passam a ser interlocutores do diálogo. Motivados por uma ecologia integral, os padres sinodais sugerem a formação de agentes de comunicação autóctones, sobretudo indígenas, como interlocutores, a fim de promover a evangelização e a promoção humana no território, e que também ajudem a Igreja na difusão da "cultura do 'bem viver' e do cuidado da criação" (DSA 60). É nesse clima de diálogo que se dará a inculturação do Evangelho, conforme proposta do papa Francisco em Querida Amazônia.

\subsection{Inculturação do Evangelho}

Uma das questões mais importantes na missão da Igreja, da qual ela encontra-se devedora aos povos indígenas, é a evangelização. Outrora ocorrida por imposição, cujo método adotado foi uma pedagogia da negação, quando então houve um processo de deculturação das crenças indígenas, agora a Igreja, movida pelo projeto de uma nova evangelização, a se dar de forma inculturada, dirige um novo olhar para os povos indígenas da Amazônia, de forma a respeitar sua cultura, reconhecendo nelas, pela via do diálogo, as sementes do Verbo, outrora negadas, que preparou a semeadura para o Evangelho.

Caminhos de Diálogo, Curitiba, ano 8, n. 12, p.77-90, jan./jun. 2020

86 ISSN 2595-8208 
Assim, a fim de conseguir uma renovada inculturação do Evangelho na Amazônia, a Igreja necessita ouvir "a sua sabedoria ancestral, voltar a dar voz aos idosos, reconhecer os valores presentes no estilo de vida das comunidades ativas, recuperar a tempo as preciosas narrações dos povos". Os valores a serem considerados pela Igreja, que tem suas raízes nas culturas pré-colombianas, são: abertura à ação de Deus; sentido da gratidão pelos frutos da terra; caráter sagrado da vida humana e a valorização da família; sentido de solidariedade, bem como de corresponsabilidade no trabalho comum. Por fim, "a importância do cultural, a crença em uma vida para além da terrena e tantos outros valores" (QA 70).

É nesse contexto que os povos indígenas da Amazônia expressam o "bem viver", cuja qualidade de vida "implica uma harmonia pessoal, familiar, comunitária e cósmica", manifestando-se "no seu modo comunitário de conceber a existência, na capacidade de encontrar alegria e plenitude numa vida austera e simples, bem como no cuidado responsável da natureza que preserva os recursos para as gerações futuras" (QA 71). A contribuição desses povos para um programa global voltado à sustentabilidade da vida no Planeta vai no sentido de "ajudar-nos a descobrir o que é uma sobriedade feliz e, nesta linha, "têm muito para nos ensinar" (QA 71). Em seu processo de inculturação do Evangelho, a Igreja não pode deixar de "apreciar esta espiritualidade indígena da interconexão e interdependência de todo o criado, espiritualidade de gratuidade que ama a vida" (QA 73).

Enquanto uma Igreja pobre, que caminha junto aos pobres, ela se faz solidária às comunidades indígenas, a fim de salvaguardar "o direito de terem uma vida própria e em paz, respeitando os valores de suas tradições, costumes e culturas, a preservação dos rios e florestas, que são espaços sagrados, fonte de vida e sabedoria". Como defensora da vida em todos os sentidos, o serviço pastoral da Igreja "constitui um serviço à vida plena dos povos indígenas", que a obriga "a proclamar Jesus Cristo e a boa nova do Reino de Deus, para frear as situações de pecado, as estruturas de morte, a violência e as injustiças internas e externas e a promover o diálogo intercultural, inter-religioso e ecumênico" (DSA 80).

Como parte do processo de inculturação da espiritualidade cristã nas culturas dos povos indígenas, está a liturgia, aberta a inovar-se com introdução de "muitos elementos próprios da experiência dos indígenas no seu contato íntimo com a natureza e estimular expressões autóctones em cantos, danças, ritos, gestos e símbolos", alinhando-se, desse modo, ao Concílio Vaticano II, que "solicitara este esforço de inculturação da liturgia nos povos indígenas, mas passaram-se já mais de cinquenta anos e pouco avançamos nesta linha” (QA 82), apesar da realização das conferências episcopais responsáveis pela receptividade do Vaticano II na América Latina.

\section{CONSIDERAÇÕES FINAIS}

Entra ano e sai ano e os povos indígenas, que no passado tiveram suas terras invadidas e surrupiadas, bem como suas culturas pulverizadas, continuam a viver o seu drama, ao serem 


\section{Revista Brasileira de Diálogo Ecumênico e Inter-religioso}

ignorados, usurpados, expulsos de suas terras e assassinados. A floresta amazônica em que habitam também padece de igual drama, ao ser estupidamente depredada, sofrendo, sobretudo, com constantes desmatamentos e incêndios. Para os povos da Amazônia, "abusar da natureza significa abusar dos antepassados, dos irmãos e irmãs, da criação e do Criador, hipotecando o futuro". Enquanto permanecem em seus territórios, os indígenas são os que melhor cuidam da natureza (QA 42).

Mostrando uma total adesão a tudo o que tem vida, e alinhando-se à consciência global de que habitamos uma casa comum, o papa Francisco tem se posicionado com voz forte, como se expressa, principalmente na Laudato si', a favor da sustentabilidade da vida no planeta, com a devida preservação do meio ambiente. Frente ao desrespeito pelas vidas e pelas terras dos povos indígenas, o papa Francisco afirma, em tom profético, que "não podemos permitir que a globalização se transforme num "novo tipo de colonialismo"' (QA 14). Conforme denuncia o papa, na depredação da natureza, bem como no desrespeito ao direito dos povos nativos a ter seu próprio território demarcado, tornou-se usual empresas sedentas pelo lucro lançarem mão de "recursos desprovidos de qualquer ética, como penalizar os protestos e mesmo tirar a vida aos indígenas que se oponham aos projetos", provocando intencionalmente incêndios florestais, ou subornando políticos e até mesmo os próprios nativos (QA 14). O papa defende que "cuidar dos valores culturais dos grupos indígenas deveria ser interesse de todos, porque a sua riqueza é também a nossa". Se não houver progresso na "corresponsabilidade pela diversidade que embeleza a nossa humanidade, não se pode pretender que os grupos do interior da floresta se abram ingenuamente à 'civilização"' (QA 37).

Conforme humildemente reconheceu o papa João Paulo II, por ocasião da comemoração dos 500 anos da chegada dos europeus à América, a Igreja tem uma dívida impagável com os povos indígenas, pois foi protagonista de um processo de deculturação de suas crenças, hábitos e costumes, quando se juntou aos invasores desse continente, com o propósito de cristianizar esses povos, que aqui se encontravam há milhares de anos. À luz dos erros do passado, hoje, a Igreja procura aliar-se aos povos indígenas, em vista à preservação de sua cultura, de suas vidas e do ambiente em que vivem. Com a realização do Concílio Vaticano II, imaginou-se que as coisas melhorariam na América Latina em relação ao drama vivido pela natureza e pelos povos indígenas. Contudo, o que se vê, apesar das conferências episcopais e da opção preferencial pelos pobres, que vem sendo reiterada desde Puebla, é que os povos originários desse continente, sobretudo os da Amazônia, continuam sendo os pobres dentre os mais pobres, juntamente com a natureza.

O passo que esperamos ser decisivo da Igreja atual, no sentido de minorar a situação dramática da Amazônia e de seus habitantes, sobretudo os indígenas, foi dado pela realização do Sínodo da Amazônia. Os participantes desse sínodo mostraram-se cônscios do drama vivido pelos povos indígenas, perante a destruição que afeta não só seu território, mas constitui uma ameaça à sua própria vida (DSA 2). No sínodo, a Igreja se integra à voz da Amazônia, cujos Caminhos de Diálogo, Curitiba, ano 8, n. 12, p.77-90, jan./jun. 2020 
povos originários são hoje protagonistas do cuidado, proteção e defesa de seus próprios direitos, bem como os da natureza (DSA 74), colocando-se em posição do auditus fidei, a fim de discernir melhor a voz do Espírito Santo, que a conduz "a novos caminhos de presença, evangelização e diálogo intercultural na Amazônia" (DSA 4). Como verdadeira aliada dos povos indígenas, a Igreja elabora propostas pastorais a fim de acabar de vez com seu sofrimento, abraçando, com eles, o paradigma de uma ecologia integral (DSA 4), salvaguardando tudo o que de vida na Amazônia, atendendo, de sua parte, ao clamor mundial pela sustentabilidade no planeta Terra.

\section{REFERÊNCIAS}

ARCONADA, Katu. Descolonização e viver bem são intrinsecamente ligados. IHU On-line, 23 ago. 2010. Disponível em: 〈http://www.ihuonline.unisinos.br/artigo/3439-katu-arkonada-1〉. Acesso em: 20 abr. 2020.

BOFF, Leonardo. O viver melhor ou bem viver? In: VIGIL, José M.; CASALDÁLIGA, Pedro (Orgs.). Agenda Latino-americana 2012: bem viver-bem conviver. Goiânia: Comissão Dominicana de Justiça e Paz do Brasil, 2012. p. 66.

CHAMBE, Juan Jacobo Tancara. O regresso à Pachamama: racionalidade indígena e Mãe Terra. In: VIGIL, José M.; CASALDÁLIGA, Pedro (Orgs.). Agenda Latino-americana 2010: salvemo-nos com o planeta. São Paulo: Ave Maria, 2010.

FRANCISCO. Querida Amazônia: exortação apostólica pós-sinodal ao povo de Deus e a todas as pessoas de boa vontade. São Paulo: Paulinas, 2020.

GARAY, Joaquín Ernesto. Possíveis contribuições da teologia pluralista de libertação à construção de uma ética mundial. In: TOMITA, Luiza E.; BARROS, Marcelo; VIGIL, José M. (Orgs.). Teologia latino-americana pluralista da libertação. São Paulo: Paulinas, 2006. p. 261-276.

GEFFRÉ, Claude. O lugar das religiões no plano da salvação. In: TEIXEIRA, Faustino (Org.). O diálogo inter-religioso como afirmação da vida. São Paulo: Paulinas, 1997. p. 111-138.

GIACCARIA, Bartolomeu. Índios fazem teologia. Primeiro Encontro Latino-Americano de Teologia Indígena. Perspectiva Teológica, Belo Horizonte, v. 23, n. 59, p. 105-114, jan./abr. 1991. Disponível em: 〈http://faje.edu.br/periodicos/index.php/perspectiva/article/view/1344/1737>. Acesso em: 27 abr. 2020.

HECK, Egon Dionísio. 500 anos de conquista e dominação. In: RAMPINELLI, Waldir José; OURIQUES, Nildo Domingos (Orgs.). Os 500 anos: a conquista interminável. Petrópolis: Vozes, 1999. p. 13-26.

IRARRÁZAVAL, Diego. Reimplantação teológica na fé indígena. In: ASSOCIAÇÃO ECUMÊNICA DE TEÓLOGOS/AS DO TERCEIRO MUNDO (Org.). Pelos muitos caminhos de Deus: desafios do pluralismo religioso à Teologia da Libertação. Goiás: Rede, 2003. p. 8596.

KNITTER, Paul. Prólogo. In: VIGIL, José M.; TOMITA, Luiza E.; BARROS, Marcelo (Orgs.). Teologia pluralista libertadora intercontinental. São Paulo: Paulinas, 2008. p. 7-13.

PÁDUA, Jorge Hage. Teologia negra da libertação: expressão teológica dos oprimidos na América Latina. Estudos Teológicos, São Leopoldo, v. 39, n. 2, p. 143-166, maio/ago. 1999. Caminhos de Diálogo, Curitiba, ano 8, n. 12, p. 77-90, jan./jun. 2020 
Revista Brasileira de Diálogo Ecumênico e Inter-religioso

Disponível em: 〈http://periodicos.est.edu.br/index.php/estudos_teologicos/article/view/715/650〉. Acesso em: 28 abr. 2020.

RIBEIRO, Darcy. O povo novo que somos. In: VIGIL, José Maria. Agenda Latino-americana 1993. São Paulo: Musa Editora, 1992.

ROJAS, Marilu. Espiritualidade - uma atitude perante a vida e seus desafios. IHU On-line, 5 out. 2012. Disponível em: 〈http://www.ihuonline.unisinos.br/artigo/4685-marilu-rojas >. Acesso em: 10 abr. 2020.

SANTA SÉ. Amazônia: novos caminhos para a Igreja e para uma ecologia integral. Documento final da Assembleia Especial do Sínodo dos Bispos para a região Pan-Amazônica. Brasília: Edições CNBB, 2019.

TAMAYO, Juan José. Otra teología es posible: pluralismo religioso, interculturalidad y feminismo. Espanha: Herder, 2011.

ZWETSCH, Roberto E. Perspectivas de diálogo entre fé indígena e fé cristã. Estudos Teológicos, São Leopoldo, v. 36, n. 1, p. 45-60, jan./abr. 1996. Disponível em: $\langle$ http://periodicos.est.edu.br/index.php/estudos_teologicos/article/view/810/740>. Acesso em: 29 abr. 2020.

Recebido em: 29/05/2020. Aceito em: 19/07/2020. 